\title{
Spatial Modeling for Determining Managerial Options for Structuring Productivity in KPH Bogor
}

\author{
Ricca Rohani Hutauruk ${ }^{1,2}$, Nining Puspaningsih ${ }^{3}$, Muhammad Buce Saleh \\ ${ }^{1}$ Graduate School of Bogor Agricultural University, Dramaga Main Road, Campus IPB Dramaga, Bogor, \\ Indonesia 16680 \\ ${ }^{2}$ Environment and Forestry Education and Training Bogor Agency, \\ The Ministry of Environment and Forestry, J1. Prada Samlawi Rumpin, Bogor, Indonesia \\ ${ }^{3}$ Department of Forest Management, Faculty of Forestry, Bogor Agricultural University, Academic Ring Road, \\ Campus IPB Dramaga, PO Box 168, Bogor, Indonesia 16680
}

Received Agustus 23, 2016/Accepted October 20, 2016

\begin{abstract}
In the past few years, forest management unit (KPH) Bogor has experienced many problems, technical, environmental and social, affecting the company's finances. This condition requires new breakthroughs in the form of managerial options in managing the forests of KPH Bogor. At present, KPH Bogor has formulated 12 managerial options. The purpose of this study is to build a spatial model in selecting managerial options at site level. The spatial models were built based on the score of each land unit which was obtained from expert judgment using an intensity scale, while weight was obtained using a pairwise comparison, resulting in the following equation: total score $=0.14$ $\left(0.06 x_{1}+0.11 x_{2}+0.09 x_{3}+0.08 x_{4}+0.10 y x_{5}+0.31 x_{6}+0.25 x_{7}\right)+0.72\left(0.08 y_{1}+0.22 y_{2}+0.46 y_{3}+0.13 y_{4}+0.12 y_{5}\right)$ $+0.14\left(0.45 z_{1}+0.05 z_{2}+0.44 z_{3}+0.06 z_{4}\right)$. The resulting total score was then divided into 5 classes using the equal interval method. The results for each of the managerial options were then aggregated using GIS to create KPH Bogor's management pattern. In areas where there was an overlap due to the similarity in options, a decision support system using neighboring similarity spatial analysis was used. This step allowed the spatial model to be built with many biophysical, social, and economic variables. This spatial model could map 12 types of managerial options at site level in the production structuring in KPHBogor.
\end{abstract}

Keywords: forest management unit, multi-criteria analysis, geographic information system, Perhutani

*Correspondenceauthor,email: ricca_brit@yahoo.com,ph.:+62-81317008648

\section{Introduction}

Forest preservation is all responsibility, including kesatuan pengelolaan hutan (KPH) Bogor. KPH is a forest management unit part of Perhutani (Indonesian state-owned enterprises in the field of forestry). As a state owned enterprise in forestry, KPH Bogor is demanded to preserve the sustainability of forests for the sustainability of the business. However, in reality, sustainability is far from the reach of KPH Bogor. At the moment, KPH Bogor is facing many problems (Perhutani 2015):

1 Nearly $50 \%$ of KPH Bogor has tenurial problems $(19,836.15$ ha out of the 47,991.04 ha under KPH Bogor's control).

2 The high population in KPH Bogor with their many needs are the cause for almost all KPH Bogor land to be cultivated by people.

3 Environmental degradation within KPH Bogor's area has caused it to be declared as a national strategic area which needs integrated spatial planning, spatial utilization, and regulation of spatial utilization.
4 The degradation of the forest class structure causing it to not be a normal forest which is one criterion for sustainable forest management as sustainable yield of stands will be achieved if growth and harvesting takes place in a balanced manner.

Sustainable yield is used as a basic principle in harvesting and rely heavily on the results of regulatory system that is used. To achieve sustainability, forest product regulatory system should set the intensity of harvesting, harvesting time intervals, and the magnitude and extent of harvesting (Seydack 1995).

The condition faced by KPH Bogor requires breakthroughs in the form of managerial options in KPH Bogor's forest management. The selection of these managerial options undoubtedly require the decisions most appropriate with KPH Bogor. Decision-making in forest management planning is a complex issue because the decisions affect many parties (Varma et al. 2000 ; Davis et al. 2001; Mendoza \& Martin 2006; Balteiro \& Romero 2008; Ananda \& Herath 2009). Therefore, to avoid deterioration in management decisions, the forest management planning 
should be conducted with consideration of various criteria. Jaimes et al. (2012) stated that before making a forest management plan, it is of utmost importance to formulate the criteria to be used, namely environmental, economic, and social criteria. The fulfilment of environmental, economic, and social criteria is also a prerequisite for a sustainable forest (Davis et al. 2001).

The managerial options were obtained from Perhutani through the mechanism of focum group discussion (FGD) which was attended by experts from Perhutani and academicians from Bogor Agricultural University. The managerial options is a form of alternative management actions include the types of plants and how management that allows it to be developed in the region Perhutani management unit. The managerial options for forest production structuring were:

1 Pine trees are managed by solely Perhutani.

2 Pine trees with tourism managed by solely Perhutani.

3 Pine trees with forage fodder PLDT (pemanfaatan lahan di bawah tegakan). PLDT is the term by Perhutani for use of land below tree stands. PLDT are collaboratively managed by Perhutani and the community using the input (role) sharing and output (harvest) sharing mechanism. This option should be done with the new mechanism, in which the forward intensity Perhutani management should be improved, and sharing the results of which are usually carried out without success, changed to sharing input (role) and sharing output (results). In this mechanism, people not only considered to play a role in plant PLDT, but also major crops. So that people also get the results not only of PLDT, but also of pine trees. Because the performance refers to who gets what, everyone has different interests that can lead to conflict. Performance should be able to answer the question which one is more beneficial cooperation with the A models than model B (Schmid 2004). Therefore before making this option sharing mechanism input and sharing output should be clear beforehand.

4 Pine trees with herbs and cash crops PLDT. It is pine trees with use of land below tree stands for herbs such as lemongrass, galangal, and cash crops like corn, rice, and beans are collaboratively managed by Perhutani and the community using the input sharing and output sharing mechanism.

5 Pine trees with herbs and cash crops PLDT with tourism, managed by Perhutani and the community using the input sharing and output sharing mechanism.

6 pine trees with coffee PLDT are collaboratively managed by Perhutani and the community using the input sharing and output sharing mechanism.

7 Pine trees with coffee PLDT and tourism are collaboratively managed by Perhutani and the community using the input sharing and output sharing mechanism.

8 Mixed forests in production forest are wood-producing trees such as mahogany, umbrella trees (Maesopsis eminii), rasamala, and are managed solely by Perhutani.

9 Mixed forests with tourism managed by solely Perhutani.

10 Mixed forests, multi purpose tree species (MPTS) with herb and cash crops PLDT are collaboratively managed by Perhutani and the community using the input (role) sharing and output (harvest) sharing mechanism.

11 Mixed forests, MPTS, coffee PLDT are managed by Perhutani and the community using the input (role) sharing and output (harvest) sharing mechanism.

12 Mixed forests, MPTS, coffee PLDT, with tourism are managed by Perhutani and the community using the input (role) sharing and output (harvest) sharing mechanism.

$\mathrm{KPH}$ Bogor not only requires a decision form the management option, but it also requires a decision on the location, where the management option will be executed or implemented. The spatial model can be used to make the decision making alternative managerial options management options, for each plot.

In general, a model is defined as a simplification of the real world. Jaya (2012) stated that in geomatics, GIS spatial models include a group of processes run on spatial data to produce information which is usually spatial information in the form of a map. The results of the modeling could be used for making a decision, to conduct scientific research, or to provide general information. Several author have proposed spatial modeling that integration of GIS with based on multi criteria analysis for many advantages like forest management and ecological modeling (Guiqina et al. 2009; Guoba et al. 2010; Guoqing et al. 2011; Shang et al. 2012; Malekmohammadi \& Blouchi 2014; Purwanto et al. 2015; Sulistiyono et al. 2015; Wijaya et al. 2015). The modeling spatial approach offers several for different land uses, by combining different objectives and criteria. Spatial modeling in selecting managerial options for production structuring at KPH Bogor can also be built based on existing criteria. With the spatial modeling in selecting managerial options, it will facilitate the decision-makers in selecting management options more quickly, in order to make decisions in forest management.

The advantage of using GIS is it is able to process and present more and broader data. In addition, the data are presented spatially, making it easier to present the information pertaining to a certain area, thus making decision-making an easier task (Kangas et al. 2005). Based on the description above, the purpose of this study was to construct a spatial model for selecting site-level managerial options which include multiple criteria, namely the economic, social, and environmental criteria for the forest production structuring in KPH Bogor.

\section{Methods}

Study site This study was conducted at Bagian Kesatuan Pemangkuan Hutan (BKPH) Bogor and Jonggol. BKPH is forest management unit division of KPH Bogor. BKPH Bogor consists of 3 resort pemangkuan hutan (RPH) which is resort forest management, namely: Babakan Madang, Cipamingkis, and Cipayung. BKPH Jonggol consists of 3 RPH, namely: Gunung Karang, Tinggar Jaya, and Cariu. Administratively, BKPH Bogor and Jonggol currently on administrative area of Bogor and Cianjur, West Java Province, Indonesia.

One of the problems facing by KPH Bogor is high tenurial problem. That is why Perhutani has been identifying 


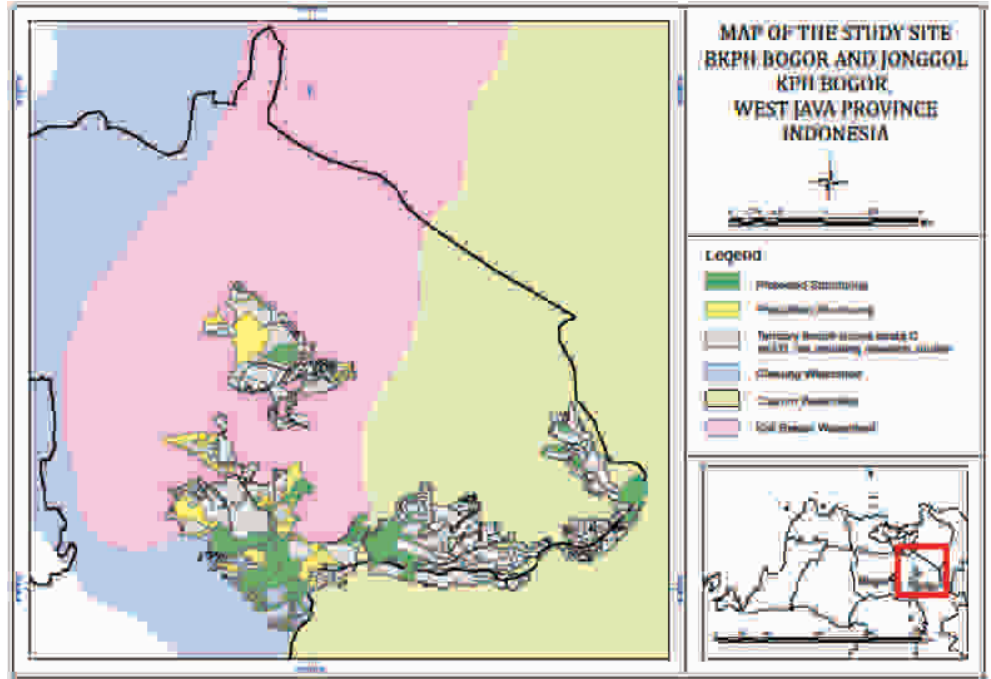

Figure 1 Study site.

and classifying problems of tenurial into 4 stratifications. First strata is strata A, which point to activities of the utilization of forest area in the region Perhutani illegally without intending to have the land (the intensity of cultivation are seasonal). Strata B, point to activities of the utilization of forest area in the region Perhutani illegally without intending to have the land, but the intensity of cultivation are throughout the year. Strata C, stand for activities of the utilization of forest area in the region Perhutani illegally and intending to have the land, but did not have any ownership documents. The last is strata $\mathrm{D}$, which refers to activities of the utilization of forest area in the region Perhutani illegally and intending to have the land, and have accompanied with a proof of ownership documents (Perhutani 2012). Based on the above description, the handling of the strata of $A$ and $B$ is certainly easier to do than the $\mathrm{C}$ and $\mathrm{D}$. Handling the $\mathrm{C}$ and $\mathrm{D}$ strata is more difficult because it needs the legal process. Therefore in this study, the area of tenurial strata $\mathrm{C}$ and $\mathrm{D}$ are removed from the study research. Area of this study is 4,619.146 ha.

Material and equipment The equipment used consisted of field observation tools such as a GPS receivers and cameras. The equipment for interviews was stationery and a recorder,

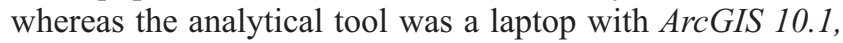
Erdas 9.1, and Mc.Excell. The materials used were questionnaires, landsat images 8 OLI (Operational Land Image/Thermal Infrared Sensor) and SRTM (Shuttle Radar Topography Mission) 1 Arc Second Global which was obtained from http://earthexplorer.usgs.gov/ for analysis of land cover and contour.

Data collection In constructing a spatial model data in the form of managerial options and the criteria used as variables in the creation of the model are required. The data were spatial and textual data obtained from Perhutani and Citarum Ciliwung River Basin Management Station. Criteria identification is also needed for constructing the spatial model for choosing managerial options. The criteria included the economic, environmental, and social criteria (multi- criteria analysis) which were made into variables in the model construction (Table 1).

Model formulation The spatial model was constructed based on the score and weight obtained from both qualitative and quantitative data. The score for each land unit was obtained from expert judgment using an intensity scale, while the weight was obtained from the pairwise comparison. Therefore a spatial model for selecting sitelevel managerial options which include multiple criteria on the weighting factors and the value of the score on each variable may be stated with mathematical equations (weighted linear combination) as shown in Equation [1]:

$$
\begin{aligned}
\mathrm{Y}= & \mathrm{A}\left(\mathrm{a}_{1} \cdot \mathrm{X}_{1}+\mathrm{a}_{2} \cdot \mathrm{x}_{2}+. . \mathrm{a}_{\mathrm{n}} \cdot \mathrm{X}_{\mathrm{n}}\right)+\mathrm{B}\left(\mathrm{b}_{1} \cdot \mathrm{y}_{1}+\mathrm{b}_{2} \cdot \mathrm{y}_{2}+. . \mathrm{b}_{\mathrm{n}} \cdot \mathrm{y}_{\mathrm{n}}\right)+ \\
& \mathrm{C}\left(\mathrm{c}_{1} \cdot \mathrm{z}_{1}+\mathrm{c}_{2} \cdot \mathrm{z}_{2}+. . \mathrm{c}_{\mathrm{n}} \cdot \mathrm{Z}_{\mathrm{n}}\right)
\end{aligned}
$$

Note: $\mathrm{Y}=$ total score, $\mathrm{A}=$ weight of environmental criteria, $\mathrm{B}$ = weight of economic criteria, $\mathrm{C}=$ weight of social criteria, $a_{1}, a_{2}, \ldots, a_{n}=$ weight of environmental variables, $b_{1}, b_{2}, \ldots, b_{n}=$ weight of economic variables, $c_{1}, c_{2}, \ldots, c_{n}=$ weight of social variables, $\mathrm{x}_{1}, \mathrm{x}_{2}, \ldots, \mathrm{x}_{\mathrm{n}}=$ score of environmental variables, $\mathrm{y}_{1}$, $\mathrm{y}_{2}, \ldots, \mathrm{y}_{\mathrm{n}}=$ score of economic variables, $\mathrm{z}_{1}, \mathrm{z}_{2}, \ldots, \mathrm{z}_{\mathrm{n}}=$ score of social variables.

Scoring method The class criteria (Table 1) were used as a variable to obtain the score for each managerial option. Each variable was given 1 (as the lowest score) to 3 (as the highest). One was given if a variable was an obstacle or was not suitable for the chosen option. Three was given if a variable supported the chosen option. An example is the option where pine is managed by Perhutani, the scores given based on the altitude variable (msal) are as follows: (a) Altitude class $<500$ msal was given a score of 1 because at thet altitude pine does not grow well, (b) Altitude class $>1,000$ msal was given a score of 2 because pine can still reach optimum growth at an altitude of 1,700 msal, but the resin decreases. The higher the altitude, the lower the temperature gets. The average decrease in temperature according to altitude in Indonesia is 5 to $6^{\circ} \mathrm{C}$ every $1,000 \mathrm{~m}$ (Siswamartana et al. 2002; Handoko 1995 in Rusdiana \& Amalia 2012). Further altitude class of 500-1,000 msal was 
Table 1 Criteria and variables used to construct a spatial model

\begin{tabular}{|c|c|c|c|c|c|c|c|}
\hline Criteria & Variables & unit & & & Level & & \\
\hline \multirow{6}{*}{ Environmental } & Altitude $^{a}$ & (m. asl.) & $<500$ & $500-1000$ & $>1000$ & - & \multirow{2}{*}{$\begin{array}{c}- \\
>40\end{array}$} \\
\hline & Area slope ${ }^{b}$ & $(\%)$ & $0-8$ & $8-15$ & $15-25$ & $25-40$ & \\
\hline & Type of soil ${ }^{\mathrm{b}}$ & - & $\begin{array}{c}\text { alluvial, glei } \\
\text { planosol, gray } \\
\text { hidroworf, laterita } \\
\text { ground water }\end{array}$ & Latosol & $\begin{array}{l}\text { brown forest } \\
\text { soil, non calcis } \\
\text { brown, } \\
\text { mediteran }\end{array}$ & $\begin{array}{l}\text { andosol, laterit, } \\
\text { grumosol, podsol, } \\
\text { podsolik }\end{array}$ & $\begin{array}{l}\text { regosol, } \\
\text { litosol, } \\
\text { organosol, } \\
\text { renzina }\end{array}$ \\
\hline & Depth of solum ${ }^{\mathrm{ac}}$ & $\mathrm{cm}$ & $<30$ & $30-60$ & $>60$ & - & - \\
\hline & $\begin{array}{l}\text { High conservation } \\
\text { value forest }(\mathrm{HCVF})^{\mathrm{c}, \mathrm{d}}\end{array}$ & - & not HCVF area & HCVF area & - & - & - \\
\hline & Erosion rate ${ }^{\mathrm{e}}$ & ton/ha/year & $<15$ & $15-60$ & $60-180$ & $180-480$ & $>480$ \\
\hline \multirow{4}{*}{ Economic } & Forest class $^{c}$ & - & $\begin{array}{c}\text { special purpose } \\
\text { district }\end{array}$ & $\begin{array}{c}\text { pine trees } \\
\text { district }\end{array}$ & $\begin{array}{l}\text { mixed forests } \\
\text { district }\end{array}$ & $\begin{array}{l}\text { not good for } \\
\text { production }\end{array}$ & vacant lot \\
\hline & Type of plant ${ }^{\mathrm{c}}$ & - & SAP producing plant & mixed forests & nothing & - & - \\
\hline & Tourism potential $^{\mathrm{c}}$ & - & potential area & $\begin{array}{c}\text { not the potential } \\
\text { area }\end{array}$ & - & - & - \\
\hline & Labor availability $^{\mathrm{c}}$ & - & Easily & difficult & - & - & - \\
\hline \multirow{4}{*}{ Social } & Theft intensity $^{\mathrm{c}}$ & - & Nothing & low & high & - & - \\
\hline & $\begin{array}{l}\text { Intensity of cutting fallen } \\
\text { trees into firewood }{ }^{c}\end{array}$ & - & Nothing & low & \multirow{3}{*}{$\begin{array}{c}\text { high } \\
\text { throughout the } \\
\text { year } \\
\text { high }\end{array}$} & - & - \\
\hline & Cultivation intensity $^{c}$ & - & Nothing & low & & - & - \\
\hline & Grazing intensity ${ }^{\mathrm{c}}$ & - & Nothing & low & & - & - \\
\hline
\end{tabular}

${ }^{\mathrm{a}}$ Hardjowigeno and Widiatmika (2007); ${ }^{\mathrm{b}}$ Pertanian (1981); ${ }^{\mathrm{c} P e r h u t a n i}(2015) ;{ }^{\mathrm{d}}$ Konsorsium Revisi HCV Toolkit Indonesia (2008); ${ }^{\mathrm{e}}$ Wischmeir and Smith (1978).

given a score of 3 because at this altitude pine reaches its optimum growth. This was how the score for each class criteria for each managerial option was determined.

The weight method Weight was determined pairwise comparison with the analytic hierarchy process (AHP) method. The AHP is a theory of measurement through pairwise comparisons and relies on the judgements of experts to derive priority scales (Saaty 2008). The calculation of the weights, done with steps as follows:

1 Developing a pair wise comparison matrix for each criterion. A scale of numbers to make comparisons, that indicates how important or dominant one element to another element which they are compared, namely: 1 (equal importance), 3 (moderate importance of 1 factor over another), 5 (strong or essential importance), 7 (very strong importance), 9 (extreme importance), while $2,4,6,8$ values for inverse comparison.

2 Normalizing the resulting matrix.

3 Averaging the values in each row to get the corresponding rating.

4 Calculating and checking the consistency ratio. The purpose for doing this is to make sure that the original preference ratings were consistent. Because it will be hard to get a consistent comparison results matrix, when using many variables. Calculating and checking the consistency ratio, done with steps as follows: (1) calculate the consistency measure $\left(\lambda\right.$ maks $\left.=\frac{2}{2}\right),(2)$ calculate the consistency index (CI) with the following equation: $\mathrm{CI}=\frac{\mathrm{n}}{\mathrm{n}-1}$ (3) calculate the consistency ratio (CR) with the following equation : $\mathrm{CR}=\frac{\mathrm{c}}{\mathrm{w}}$, where $\mathrm{RI}$ $($ Random Index $)=1.98(n-2) / n, C R$ magnitude smaller than $0.1(10 \%)$ means that the original preference ratings were consistent (Jaya 2012).

Obtain the land suitability map for one managerial option. The results of the score and weight were then recalculated in a weighted linear combination. The result was the total score which would be divided into 5 classes using the equal interval method as shown as Equation [2]:

Equal interval $=\frac{\text { Maximum score }- \text { Minimum score }}{\text { The number of classes }}$

The suitability of each class for the chosen option was stated using the following values: very suitable (if the total score was <1.40), unsuitable (if the total score was between 1.40-1.79), fairly suitable (if the total score was between 1.80-2.19), suitable if the total score was between (2.20-2.59), and very suitable (if the total score was $>2.60$ ).

Managerial option selection mapping The results for each managerial option were then aggregated using GIS to produce KPH Bogor's management pattern. The steps taken were by overlaying the entire land suitability map for each managerial option for production structuring with the Perhutani plot map. Then the most suitable option for each spatial unit was selected. If in one spatial unit there was one option that was very suitable and one that was suitable, this is automatically chosen. If there were any obstacles in this phase, for example there is an overlap because in the same area there are options with the same level of suitability (for example in one spatial unit there was a match at "fairly suitable at option 1" and "fairly suitable at option 3"), the decision support system was conducted with similarity with neighbor spatial analysis. In spatial units with 2 or 3 options 


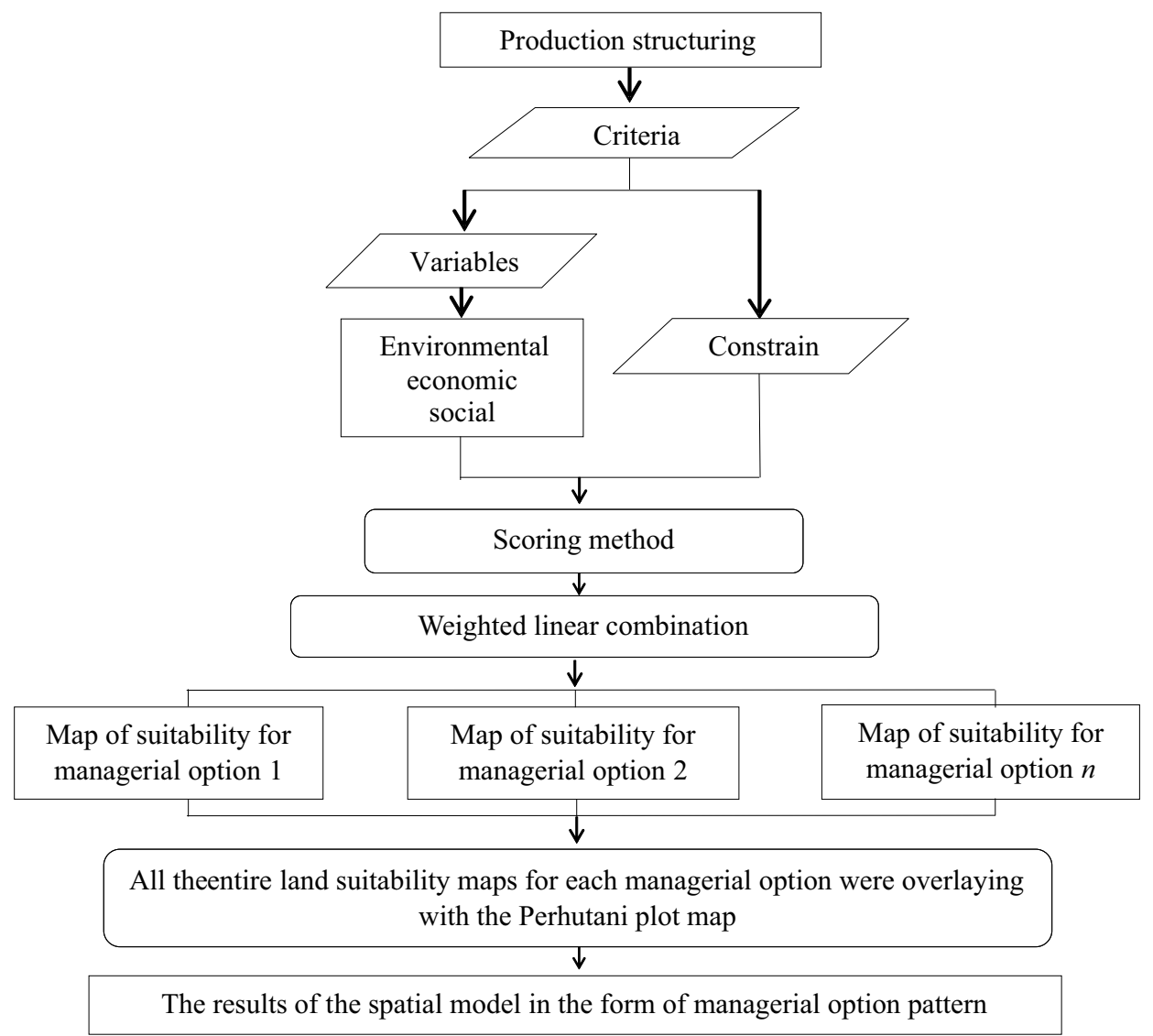

Figure 2 Stage of construction spatial modeling in selecting managerial options.

with the same suitability, what is noted was the the chosen option in the closest spatial unit. The chosen option in that spatial unit was the most dominant option in the adjacent area. This phase was conducted using GIS. The managerial option modeling phase can be seen in Figure 2.

Verification of managerial options with the level of erosion Given KPH Bogor is the area "Bopunjur", then his role as protection functions are concerned. Therefore, the managerial option selected is verified by attrition rate is calculated from the condition of land cover with the assumption that these options have been successfully implemented. The purpose of verification to see if the selected managerial option can reduce the rate of erosion in the region or vice versa. The equation used in predicting erosion was based on the Universal Soil Loss Equation (USLE) method (Wischmeir \& Smith 1978; Nagaraju et al. 2011), as shown as Equation [3].

$\mathrm{EA}=\mathrm{R} \times \mathrm{K} \times \mathrm{Ls} \times \mathrm{Cp}$

Note: $\mathrm{EA}=$ erosion rate, $\mathrm{R}=$ erosivity, $\mathrm{K}=$ erodibility, $\mathrm{LS}=$ length and slope, $\mathrm{C}=$ land use factor, $\mathrm{P}=$ soil conservation factor.

\section{Results and Discussion}

Scoring The production arrangement area in BKPH Bogor and Jonggol had land units with different biophysical, social, and economic characteristics. Based on the altitude, the study site varied between $250 \mathrm{msal}-1,675 \mathrm{msal}$, and the area slope was also varied from flat $(0-8 \%)$ to steep $(>40 \%)$. The dominant soil type was grumosol, latosol, and podsol. The depth of solum also varied, from shallow $(<30 \mathrm{~cm})$ to deep $(>60 \mathrm{~cm})$. The HCV criteria at BKPH Bogor and Jonggol was within the protected forest class, while in the production arrangement there was no HCVF. From the erosion prediction which was analyzed from the land cover and 2015 precipitation data, the study site had prone and highly prone to erosion areas which covered $4.01 \%$ (185.28 ha) of the total production area being arranged, which was $4,619.15$ ha. The social and economic characteristics of the study site were also varied when seen from the forest class, types of plants growing during observation (in 2015), whether there was tourism potential, the managerial accessibility, and labor. This was also the case in theft, cutting fallen trees into firewood, cultivation, and grazing intensity.

These diverse data need to be standardized through the granting of a score. Domiri (2012) stated that giving the value of the score is to standardize the independent variables of a different unit and its characteristics being equal, so it can be used together to create thematic information. Each land unit with those different characteristics had different scores based on the available options. Each unit of land was then recalculated using a weighted linear combination (Equation [1] to obtain the land suitability map for each managerial option. Table 2 is an example of the results awarding score on Pine trees are managed by solely Perhutani option. 
Table 2 Score used for pine trees are managed by solely Perhutani

\begin{tabular}{|c|c|c|c|}
\hline Criteria & Variables & Level & Score \\
\hline \multirow{21}{*}{ Environmental } & \multirow{3}{*}{ Altitude } & $<500$ & 1.00 \\
\hline & & $500-1000$ & 3.00 \\
\hline & & $>1000$ & 2.00 \\
\hline & \multirow{4}{*}{ Area slope } & $0-8 \%$ & 3.00 \\
\hline & & $8-15 \%$ & 3.00 \\
\hline & & $15-25 \%$ & 2.62 \\
\hline & & $25-40 \%$ & 2.00 \\
\hline & \multirow{2}{*}{ Type of soil } & Latosol (slightly sensitive) & 2.00 \\
\hline & & Grumosol, podsolik (sensitive) & 1.26 \\
\hline & \multirow{3}{*}{ Depth of solum } & Shallow $(<30 \mathrm{~cm})$ & 1.00 \\
\hline & & Medium $(30-60 \mathrm{~cm})$ & 2.00 \\
\hline & & Very deep $(>60 \mathrm{~cm})$ & 3.00 \\
\hline & \multirow[b]{2}{*}{ Rocks } & Slight $(0.01 \%)$ & 3.00 \\
\hline & & Medium $(0.01-0.1 \%)$ & 2.00 \\
\hline & \multirow{2}{*}{ HCVF area } & Not HCVF area & 3.00 \\
\hline & & HCVF area & 1.00 \\
\hline & \multirow{5}{*}{ Erosion rate } & Very low $\left(<15\right.$ ton ha $^{-1}$ year $\left.^{-1}\right)$ & 3.00 \\
\hline & & Low $\left(15-60\right.$ ton ha $^{-1}$ year $\left.^{-1}\right)$ & 3.00 \\
\hline & & Medium (60-180 ton ha $^{-1}$ year $\left.^{-1}\right)$ & 2.00 \\
\hline & & High $\left(180-480\right.$ ton ha $^{-1}$ year $\left.^{-1}\right)$ & 1.26 \\
\hline & & Very high $\left(>480\right.$ ton ha $^{-1}$ year $\left.^{-1}\right)$ & 1.00 \\
\hline \multirow{12}{*}{ Economic } & \multirow{5}{*}{ Forest class } & Special purpose district & 2.00 \\
\hline & & Pine trees district & 3.00 \\
\hline & & Mixed forests district & 1.00 \\
\hline & & Not good forproduction & 1.00 \\
\hline & & Vacant lot & 3.00 \\
\hline & \multirow{3}{*}{ Type of plant } & Nothing & 3.00 \\
\hline & & SAP producing plant & 3.00 \\
\hline & & Rimba lain & 1.00 \\
\hline & Tourism potential & Tourism potential area & 2.00 \\
\hline & Accessibility & Difficult & 1.00 \\
\hline & \multirow{2}{*}{ Labor availability } & Easily & 3.00 \\
\hline & & Difficult & 1.00 \\
\hline \multirow{12}{*}{ Social } & \multirow{3}{*}{ Theft intensity } & Nothing & 3.00 \\
\hline & & Low & 2.00 \\
\hline & & High & 1.00 \\
\hline & \multirow{3}{*}{ Intensity of cutting fallen trees into firewood } & Nothing & 3.00 \\
\hline & & Low & 2.00 \\
\hline & & High & 1.00 \\
\hline & \multirow{3}{*}{ Cultivation intensity } & Nothing & 3.00 \\
\hline & & Low & 2.00 \\
\hline & & Throughout the year & 1.00 \\
\hline & \multirow{3}{*}{ Grazing intensity } & Nothing & 3.00 \\
\hline & & Low & 2.00 \\
\hline & & High & 1.00 \\
\hline
\end{tabular}

Weight Each variable had a level of interest. The level of interest was quantified into scoring and weight in the construction of the managerial option selection spatial model. The results of the weighting were calculated using pairwise comparison with the AHP method (Table 3). In production forest arrangement, the economic criteria are the most important, which accounts for $72 \%$ but also observes the environmental and social criteria environment which are equally important at $14 \%$.

The spatial model was constructed based on the score and weight obtained from both qualitative and quantitative data.
Therefor the relationship between managerial option selection based on the spatial analysis of multi criteria with weighting factors in Table 3 and the values of the score on each variable can be described by the following mathematical equation (weighted linear combination) as shown as Equation [4]:

Total score $=0.14\left(0.06\right.$ score $\mathrm{x}_{1}+0.11$ score $\mathrm{x}_{2}+0.09$ score $\mathrm{x}_{3}+$ 0.08 score $\mathrm{x}_{4}+0.10$ score $\mathrm{x}_{5}+0.31$ score $\mathrm{x}_{6}+0.25$ score $\left.\mathrm{x}_{7}\right)+$ $0.72\left(0.08\right.$ score_ $\mathrm{y}_{1}+\overline{0} .22$ score_ $\mathrm{y}_{2}+0.46$ score_- $\mathrm{y}_{3}+$ 0.13 score $\mathrm{y}_{4}+0.12$ score $\left.\mathrm{y}_{5}\right)+0.14\left(0.45\right.$ score $\mathrm{z}_{1}+$ 0.05 score $z z_{2}+0.44$ score $z_{3}+0.06$ score $z_{4}$ ) 
Table 3 The weight of criteria and variables used in the spatial model

\begin{tabular}{lrr}
\hline \multicolumn{1}{c}{ Managerial options } & Total area (ha) & $\%$ \\
\hline Pine trees are managed by solely Perhutani & 154.74 & 3.35 \\
Pine trees with tourism managed by solely Perhutani & 57.78 & 1.25 \\
Pine trees with forage fodder PLDT & 97.67 & 2.11 \\
Pine trees with herbs and cash crops PLDT & 807.78 & 17.49 \\
Pine trees with herbs and cash crops PLDT with tourism & 49.82 & 1.08 \\
Pine trees with coffee PLDT & 990.73 & 21.45 \\
Pine trees with coffee PLDT with tourism & 527.73 & 11.42 \\
Mixed forests are managed solely by Perhutani & 61.50 & 1.33 \\
Mixed forests with tourism managed by solely Perhutani & 19.00 & 0.41 \\
Mixed forests, MPTS, with herbs and cash crops PLDT & 473.44 & 10.25 \\
Mixed forests, MPTS, with coffee PLDT & $1,355.59$ & 29.35 \\
Mixed forests, MPTS, with coffee PLDT with tourism & 23.36 & 0.51 \\
\hline
\end{tabular}

Obtain the land suitability map for one managerial option Each land unit with those different characteristics had different scores based on the available options. Each unit of land was then recalculated using a weighted linear combination Equation [1] to obtain the land suitability map for one managerial option. In the same way, be mapped the suitability of land for 12 managerial option. The Figure 3 is one of land suitability map option 1 , namely Pine trees are managed by solely Perhutani.

The managerial option selection mapping The resulting suitability maps for all the managerial options were then aggregated to create the managerial option pattern at BKPH Bogor and Jonggol. The steps were overlaying all the land suitability maps for each managerial option for production structuring. Because in this study there were numerous options, there were overlaps between areas with similar option; therefore, in these areas automated option selection could not be conducted. To overcome this obstacle, the decision support system using neighboring similarity spatial analysis. For spatial units with two or three similar suitability options, the chosen option in the closest neighboring unit is noted. The chosen option in that spatial unit is the one most dominant in the adjacent area. This step was conducted using GIS. Using the spatial model that had been built, the managerial option suitability map which is presented in Figure 4 was constructed. (The results of the spatial model in the form of managerial option pattern) and Table 4 (managerial options based on size).

In structuring productivity, the 3 most common options were:

1 Mixed forest MPTS with a coffee PLDT covering an area of 1355.59 ha $(29.35 \%)$.

2 Pine with coffee PLDT covering an area of 990.73 ha $(21.45 \%)$.

3 Pine with herbs and cash crops PLDT covering an area of 807.78 ha $(17.489 \%)$.

The chosen option was dominated by PLDT plants that

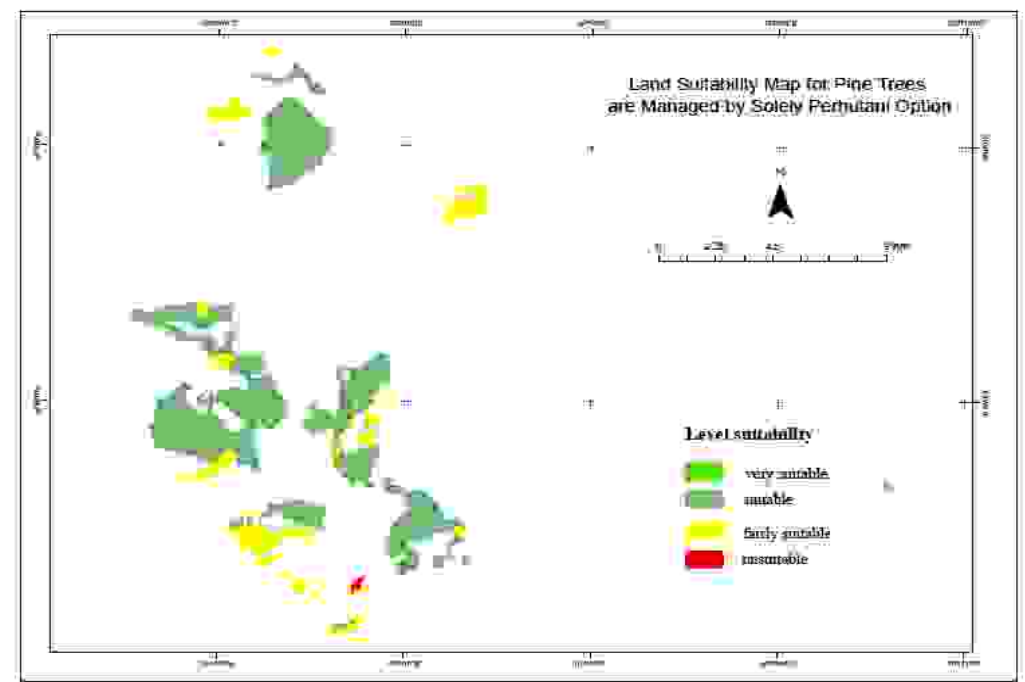

Figure 3 Land suitability map for pine trees is managed by solely Perhutani option. 


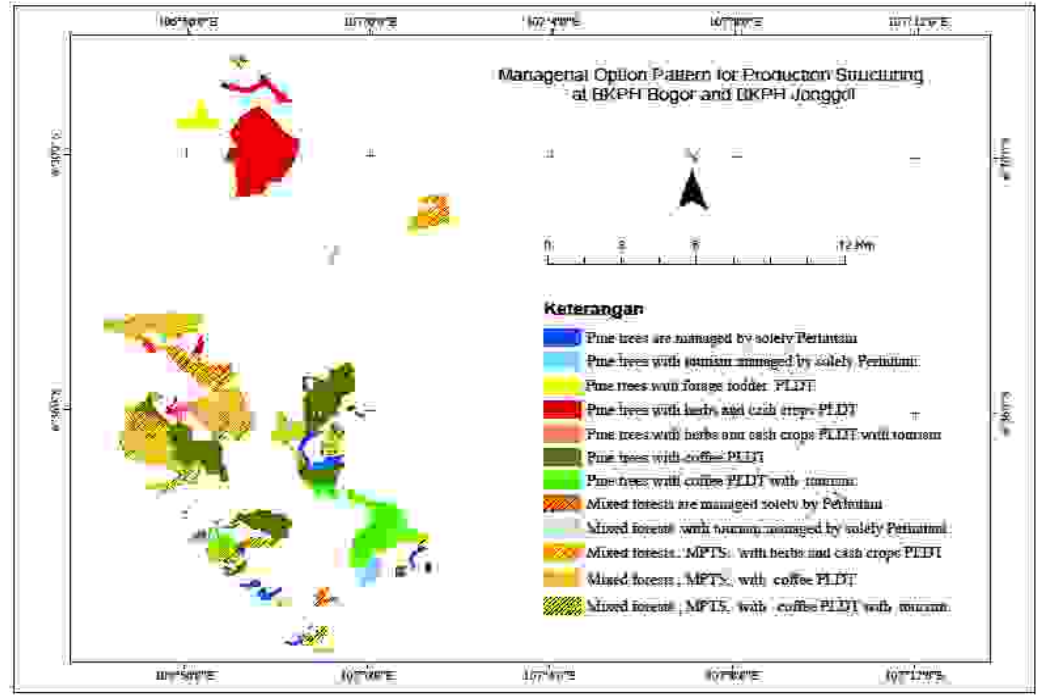

Figure 4 The results of the spatial model in the form of managerial option pattern.

Table 4 Managerial options based on total area.

\begin{tabular}{|c|c|c|c|}
\hline Criteria & Weight of criteria & Variables & Weight of variables \\
\hline \multirow{8}{*}{ Environmental } & \multirow{8}{*}{0.14} & Altitude $\left(\mathrm{x}_{1}\right)$ & 0.06 \\
\hline & & Area s lope $\left(\mathrm{x}_{2}\right)$ & 0.11 \\
\hline & & Type of soil $\left(\mathrm{x}_{3}\right)$ & 0.09 \\
\hline & & Depth of solum $\left(\mathrm{x}_{4}\right)$ & 0.08 \\
\hline & & $\operatorname{Rock}\left(\mathrm{x}_{5}\right)$ & 0.10 \\
\hline & & High conservation value forest area $\left(\mathrm{x}_{6}\right)$ & 0.31 \\
\hline & & Erosion rate $\left(\mathrm{x}_{7}\right)$ & 0.25 \\
\hline & & & 1.00 \\
\hline \multirow{6}{*}{ Economic } & \multirow{6}{*}{0.72} & Forest class $\left(\mathrm{y}_{1}\right)$ & 0.08 \\
\hline & & Type of plant $\left(\mathrm{y}_{2}\right)$ & 0.22 \\
\hline & & Tourism potential $\left(\mathrm{y}_{3}\right)$ & 0.46 \\
\hline & & Accessibility $\left(\mathrm{y}_{4}\right)$ & 0.13 \\
\hline & & Labor availability $\left(\mathrm{y}_{5}\right)$ & 0.12 \\
\hline & & & 1.00 \\
\hline \multirow{5}{*}{ Social } & \multirow{5}{*}{0.14} & Theft intensity $\left(\mathrm{z}_{1}\right)$ & 0.45 \\
\hline & & Intensity of cutting fallen trees into firewood $\left(\mathrm{z}_{2}\right)$ & 0.05 \\
\hline & & Cultivation intensity $\left(\mathrm{z}_{3}\right)$ & 0.44 \\
\hline & & Forest class $\left(\mathrm{z}_{4}\right)$ & 0.06 \\
\hline & & & 1.00 \\
\hline
\end{tabular}

involved the community. Theoretically, if the PLDT is well managed, this activity is basically an effort to return the ecological forest function (Mustofa 2011). Knowledge about the suitability of the type PLDT with the conditions of land, needed to mitigate the effects of damage to the environment, because PLDT in KPH Bogor originally performed by people without going through legal procedures, so the selection of plant species dependent on the whims PLDT surrounding communities without regard to environmental damage.

Mustafa (2011) found that plants grown on PLDT area, need to consider the type for production structuring and protected structuring, plant size and condition of forest land, especially the slope. PLDT for the production structuring should be a plant that does not interfere with the growth of tree stands, but also not cause landslides. Differently for protected structuring, that plants grown on PLDT area, should not consider with the growth of tree stands, but especially for forest preservation, and the plants need to be introduced the suitable plant that can boost the economy of farmers, easy maintenance, and also has a market and economically profitable.

Verification of managerial options with the level of erosion Managerial options with a predicted rate of erosion of managerial options, if the managerial option selected is successfully applied was calculated using the equation USLE, where the land use factor adapted to the selected option can be seen in Table 5 .

Table 5 can explain that the study site had prone to erosion areas which covered 23.83 ha and highly prone to 


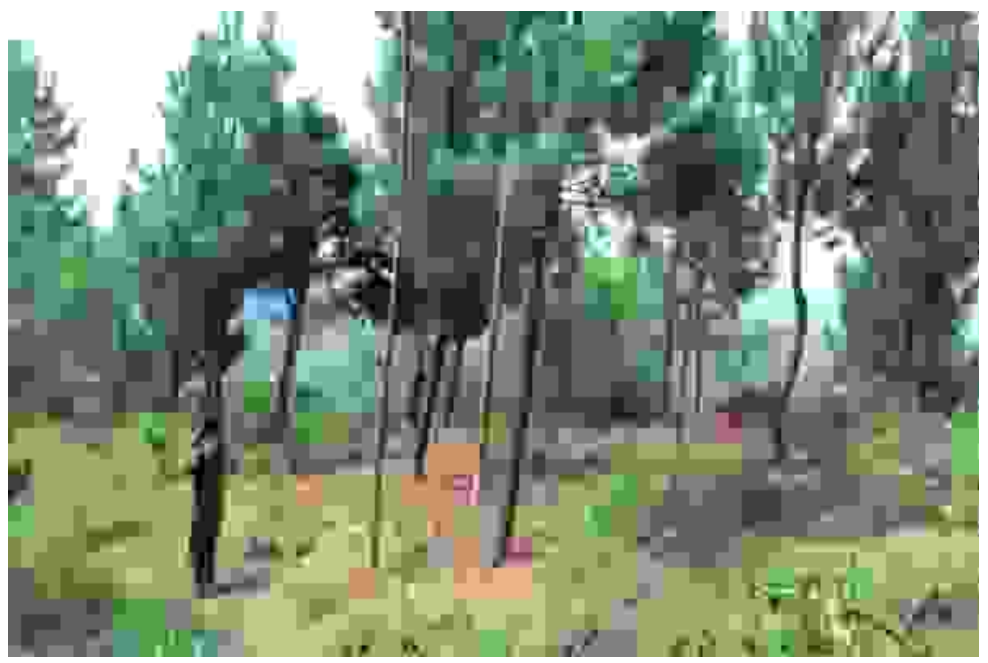

Figure 5 Pine with herbs and cash crops PLDT at KPH Bogor.

Table 5 Managerial options based on the rate of erotion

\begin{tabular}{|c|c|c|c|c|c|c|}
\hline \multirow[t]{2}{*}{ Managerial options } & \multicolumn{5}{|c|}{$\begin{array}{c}\text { Rate of erotion calculated from the condition of land cover with } \\
\text { the assumption that these options have been successfully } \\
\text { implemented (ton ha } \mathrm{a}^{-1} \text { year }{ }^{-1} \text { ) }\end{array}$} & \multirow[t]{2}{*}{$\begin{array}{l}\text { Total area } \\
\text { (ha) }\end{array}$} \\
\hline & Very low & Low & Medium & High & Very high & \\
\hline Pine trees are managed by solely Perhutani & 39.52 & 110.09 & 3.49 & 1.55 & 0.09 & 154.74 \\
\hline Pine trees with tourism managed by solely Perhutani & 53.55 & 4.23 & - & - & - & 57.78 \\
\hline Pine trees with forage fodder PLDT & 27.47 & 70.13 & 0.06 & - & - & 97.67 \\
\hline Pine trees with herbs and cash crops PLDT & 772.04 & 34.44 & 1.30 & - & - & 807.78 \\
\hline Pine trees with herbs and cash crops PLDT & 46.27 & 3.39 & 0.16 & - & - & 49.82 \\
\hline Pine trees with coffee PLDT & 480.55 & 486.76 & 22.57 & 0.84 & - & 990.73 \\
\hline Pine trees with coffee PLDT with tourism & 198.95 & 277.70 & 32.73 & 17.11 & 1.24 & 527.73 \\
\hline Mixed forests are managed solely by Perhutani & 15.86 & 41.95 & 3.07 & 0.63 & - & 61.50 \\
\hline Mixed forests with tourism managed by solely Perhutani & 18.12 & 0.87 & - & - & - & 19.00 \\
\hline Mixed forests, MPTS, with herbs and cash crops PLDT & 53.04 & 417.50 & 2.76 & 0.13 & - & 473.44 \\
\hline Mixed forests, MPTS, with coffee PLDT & 618.06 & 710.10 & 21.43 & 3.56 & 2.45 & $1,355.59$ \\
\hline Mixed forests, MPTS, with coffee PLDT with tourism & 21.76 & 1.60 & - & - & - & 23.36 \\
\hline Total & $2,345.19$ & $2,158.76$ & 87.59 & 23.83 & 3.78 & $4,619.15$ \\
\hline
\end{tabular}

erosion areas which covered 3.78 ha, with assuming a managerial option selected is successfully applied. While at the same area, the erosion prediction which was analyzed from the land cover and 2015 precipitation data, the study site had prone to erosion areas which covered 171.65 ha and highly prone to erosion areas which covered 13.631 ha. That is mean the pattern of managerial options is environmentally feasible, because if managerial options successfully implemented, can reduce the prone to erosion areas at 147.82 ha, and highly prone to erosion areas at 9.85 ha.

The study site also had prone to erosion areas and highly prone to erosion areas, persist despite managerial option is implemented. This is because the unit land at study site has characteristics very steep slopes, high rainfall, and soil vulnerable to erosion. Accordance with the opinion of Wischmeir and Smith (1978) that the rate of erosion is influenced by the number of multiplication factor, namely $\mathrm{R}$ (erosivity), K (erodibility), LS (length and slope), Cp (land use factor, and soil conservation techniques).

On the managerial options that remain prone to erosion areas and highly prone to erosion areas, need extra attention and treatment. On the management options needs to be done soil conservation measures. Soil conservation techniques can be done with a variety of treatments, both with civil engineering, vegetative, or chemical. Soil conservation techniques also do not need a single, but it can be a combination of various measures, so as a whole can provide good soil conservation effect. Some examples of conservation techniques that can be done is to create channels patio, terrace ridge, terrace credit, gully control (plug gully, gully drop, drop structure), the protection of the river springs (Hardjowigeno \& Widiatmika 2007).

This model shows the potential of GIS-based to help optimize and speed up planning procedures, to support decision making. GIS based model allows to integrate information in a systemic way, can then be used to produce 
visual output that can be measured and georeferenced, so as to facilitate decision-making (Kangas et al. 2005; Ananda \& Herath 2009; Jaimes et al. 2012). Keep in mind that to construct a spatial model, closely related to decision making that should pay attention to the various practical considerations the following: selection of the desired local, minority interest, national policy, barriers such as land tenure, availability of data, environmental standard, and practicability. It is also necessary to pay attention the implementation of the agency's potential, the cost and availability of funds (Hardjowigeno \& Widiatmika 2007).

This model provided land productivity because the chosen options did not only consist of one main vegetation, but there was the PLDT system which consisted of a variety of plants. This model also could reduce social conflict with the community because the chosen options involved the community and stakeholders.

\section{Conclusion}

The spatial model in the selection of the managerial option at site level at KPH Bogor could be built. This model was not only built on various biophysical criteria but also involved social and economic criteria. The spatial model that was built was able to map 12 types of managerial options at site level in production structuring at KPH Bogor. Patterns of managerial options is social feasible, because as selected option involves the community and stakeholders. The pattern of managerial options is also environmentally feasible, because if managerial options successfully implemented, can reduce the prone to erosion areas at 147.82 ha, and highly prone to erosion areas at 9.85 ha. The results of the research can be used by KPH Bogor management, as a basis for decision making in determining its forest management plan.

\section{References}

Ananda J, Herath G. 2009. A critical review of multi-criteria decision making methods with special reference to forest management and planning. Ecological Economics 68(10):2535-2548. https://doi.org/10.1016/j.ecolecon. 2009.05.010.

Balteiro LD, Romero C. 2008. Making forestry decisions with multiple criteria: A review and an assessment. Forest Ecology and Management 255:3222-3241. https://doi.org/ 10.1016/j.foreco.2008.01.038.

Davis LS, Johnson KN, Bettinger PS, Howard TE. 2001. Forest Management to Suistain Ecological, Economic, and Sosial Values. Fourth Edition. Boston: The McGraw-Hill Higer Education.

Domiri DD. 2012. Model spasial kerentanan produksi beras menggunakan teknologi inderaja dan SIG (Studi kasus di Kabupaten Indramayu, Jawa Barat) [disertasi]. Bogor: Bogor Agricultural University.

Hardjowigeno H, Widiatmika. 2007. Evaluasi Kesesuaian Lahan dan Perencanaan Tataguna Lahan. Yogyakarta: Gadjah Mada University Press.
Jaimes NBP, Sendra JB, Delgado MG, Plata RF, Némiga XA, Solís LRM. 2012. Determination of optimal zones for forest plantations in the state of Mexico using multicriteria spatial analysis and GIS. Journal of Geographic Information System 4(3):204-218. https://doi.org/10. 4236/jgis.2012.43025.

Jaya INS. 2012. Teknik-teknik Pemodelan Spasial dalam Pengelolaan Sumberdaya Alam dan Lingkungan. Bogor: Departemen Manajemen Hutan.

Kangas J, Store R, Kangas A. 2005 Socioecological landscape planning approach and multicriteria accept-ability analysis in multiple-purpose forest management. Forest Policy and Economics 7:603- 614. https://doi.org/10.1016/j.forpol. 2003.12.001.

Konsorsium Revisi HCV Toolkit Indonesia. 2008. Panduan Identifikasi Kawasan Bernilai Konservasi Tinggi di Indonesia. Jakarta: Tropenbos International Indonesia Programme.

[Perhutani] Perusahaan Hutan Negara Indonesia. 2012. Pedoman Penanganan dan Penyelesaian Konflik Tenurial dalam Kawasan Hutan. Jakarta: Perhutani.

[Perhutani] Perusahaan Hutan Negara Indonesia. 2014. Rencana Jangka Panjang Perum Perhutani Tahun 2015-2019. Jakarta: Perhutani.

[Perhutani] Perusahaan Hutan Negara Indonesia. 2015. Pemetaan Tipologi Tapak dan Unit Manajemen dalam Rangka Perbaikan Pengelolaan Sumberdaya Hutan Perum Perhutani. Jakarta: Perhutani.

[Pertanian] 1981. Surat Keputusan Menteri Pertanian No.680-684/Kpts/Um/1981. Jakarta: Pertanian.

Malekmohammadi B, Blouchi LR. 2014. Ecological risk assessment of wetland ecosystems using multi criteria decision making and geographic information system. Ecological Indicators 41:133-144. https://doi.org/10.10 16/j.ecolind.2014.01.038.

Mendoza GA, Martins H. 2006. Multi-criteria decision analysis in natural resource management: A critical review of methods and new modelling paradigms. Forest Ecology and Management. 230:1-22. https://doi.org/10.1016/j.fo reco.2006.03.023.

Mustofa SM. 2011. Perilaku Masyarakat Desa Hutan dalam Memanfaatkan Lahan di Bawah Tegakan. Komunitas 3(1):1-11.

Nagaraju MSS, Reddy GPO, Maji AK, Srivastava R, Raja P, Barthwal AK. 2011. Soil loss mapping for sustainable development and management of land resources in Warora Tehsil of Chandrapur District of Maharashtra: An integrated approach using remote sensing and GIS. Journal of the Indian Society of Remote Sensing 39(1):51-61. https://doi.org/10.1007/s12524-010-0055-1. 
Pemerintah Republik Indonesia. 1999. Keputusan Presiden Republik Indonesia Nomor 114/1999 tentang penataan ruang kawasan Bogor-Puncak-Cianjur. Jakarta: Sekretariat Negara.

Pemerintah Republik Indonesia. 2008. Peraturan Presiden Republik Indonesia Nomor 54/2008 tentang penataan ruang kawasan Jakarta, Bogor, Depok, Tangerang, Bekasi, Puncak, Cianjur. Jakarta: Sekretariat Negara.

Purwanto J, Rusolono T, Prasetyo LB. 2015. Spatial model of deforestation in Kalimantan from 2000 to 2013. Jurnal Manajemen Hutan Tropika 21(3):110-118. https://doi. org/10.7226/jtfm.21.3.110.

Rusdiana O, Amalia RF. 2012. Kesesuaian lahan Pinus merkusii Jungh et de Vriese pada areal bekas tegakan Tectona grandis Linn. F. Silvikultur Tropika 3:174-181.

Saaty TL. 2008. Decision making with the analytic hierarchy process. International Journal Services Sciences. 1:83-98. https://doi.org/10.1504/IJSSCI.2008.017590.

Shang ZB, He HS, Xi W, Shifley SR, Palik BJ. 2012. Integrating LANDIS model and a multi-criteria decisionmaking approach to evaluate cumulative effects of forest management in the Missouri Ozarks, USA. Ecological Modelling 229:50-63. https://doi.org/10.1016/j.ecolmo del.2011.08.014.

Seydack, A. H. W. 1995. An unconventional approach to timber yield regulation for multiaged, multispecies forest, fundamental consideration. Forest Ecology and Management Journal 77:139-153. https://doi.org/10.10 16/0378-1127(95)03577-W.
Song G, Chen Y, Tian M, Lv SH, Zhang SH, Liu S. 2010. The ecological Southwestern Mountain Region of China based on GIS and AHP method. Procedia Environmental Sciences 2:465-475. https://doi.org/10.1016/j.proenv. 2010.10.051.

Sulistiyono N, Jaya INS, Prasetyo LB, Tiryana T. 2015. Spatial model of deforestation in Sumatera Island using typological approach. Jurnal Manajemen Hutan Tropika 21(3):99-109. https://doi.org/10.7226/jtfm.21.3.99.

Guoqing Y, Haibo Y, Zhizong T, Baosen Z. 2011. Ecoenvironment quality assessment of Miyun County Based on RS and GIS. Procedia Environmental Sciences 10:2601 -2607. https://doi.org/10.1016/j.proenv. 2011.09.404.

Guiqina W, Li Q, Guoxuea L, Lijun C. 2009. Landfill site selection using spatial information technologies and AHP: A case study in Beijing, China. Journal of Environmental Management 90:2414-2421. https://oi.org/10.1016/j. jenvman.2008.12.008.

Varma V, Ferguson I, Wild I. 2000. Decision support system for the sustainable forest management. Forest Ecology and Management 128:49-55. https://doi.org/10.1016/S03781127(99)00271-6.

Wijaya PA, Saleh MB, Tiryana T. 2015. Spatial model of deforestation in Jambi Province for the periode 1990-2011. Jurnal Manajemen Hutan Tropika 21(3):128-137. https://doi.org/10.7226/jtfm.21.3.128.

Wischmeier WH, Smith DD. 1978. Predicting Rainfall Erosion Losses: A Guide to Conservation Planning. Agriculture Handbook No. 537. Washington DC: USDA/Science and Education Administration. 